\title{
English Vocabulary Learning Strategies and Metacognition Awareness of Local Undergraduates
}

\author{
Sharon Sui-Lin Lim* and Rosyati Abdul Rashid
}

Universiti Malaysia Terengganu (UMT), Terengganu

*Corresponding author. Email: sharon@umt.edu.my

\begin{abstract}
There have numerous reports, among them the Higher Education Ministry (MOHE) Survey 2008, on graduates unemployability due to weak English language proficiency. However, the problem exists prior to the students enrolment into universities. Several research have shown that the vocabulary size of local undergraduates are limited and may effect their tertiary studies as they have difficulty understanding English texts due to insuffifient vocabulary. This study on first year undergraduates at a local university was carried out to determine their English vocabulary level and the vocabulary learning strategies utilised. Besides this, the researchers wanted to see if there was a difference in vocabulary learning strategies the undergraduates utilised at university from those when they were in school as well as investigate if there was a correlation between vocabulary learning strategy with students' metacognitive awareness. 244 respondents were administered an English Vocabulary Levels Test (VLT) and then completed two questionnaires: English Vocabulary Learning Strategies Questionnaire (EVLSQ) and the Metacognition Awareness Inventory (MAI). Results from the VLT showed that about $40 \%$ of the sample did not achieve the 2000 word level while $53 \%$ were at the 2000 or 3000 word level. The data from the EVLSQ showed a positive result, indicating a significant difference between perceived us of EVLS while the respondents were at school and while at university. Data analysis also indicated that vocabulary strategies use was positively and significantly correlated with general metacognitive awareness.
\end{abstract}

Keywords: English Vocabulary Level, Vocabulary Learning Strategies, Metacognitive Awareness

\section{INTRODUCTION}

There is an analogy that between Vocabulary and grammar with building a wall, whereby vocabulary is seen as the bricks and grammar as the mortar that holds it together. In order to build strong and tall "wall", a person would need to have many "bricks" and good mortar to hold it together. In research, it has been said that students embarking on tertiary education should have a vocabulary size of 300010,000 word family. It is understandable how pre-tertiary learners are expected to have such vocabulary size as they need to read and extract information from academic texts, listen to academic talks and lectures, write papers and assignments, as well as give presentations to their peers as well as faculty members. Unfortunately, that is the not the reality of local undergraduates.

A newspaper report [1] showed that Malaysia dropped from $13^{\text {th }}$ to $22^{\text {nd }}$ place in the ranking for non-native speakers. The report further suggests that data correlations seem to imply that societies with better English proficiency are more open to equal opportunities. Indeed, a Madani Society that has higher English proficiency can indeed contribute for a prosperous nation.

There have numerous reports, among them the Higher Education Ministry (MOHE) Survey 2008, on graduates unemployability due to weak English language proficiency. However, the problem exists prior to the students enrolment into universities. Research indicates that pre-varsity students need to have at least 3,000 words to understand authentic texts and 10,000 words when beginning tertiary studies [2]-[3]. Their listening comprehension is also dependent on the lexical coverage they have, depending on the level of comprehension required. In order to have a good L2 listening comprehension at $95 \%$ coverage, an L2 learner needs to have the knowledge of 2000-3000 of the most frequent word families [4]-[5]. 
This study was carried out to ascertain the vocabulary level undergraduates at a local univeristy. The relationship between vocabulary level and the students' utilisation of English vocabulary learning strategies (VLS) to increase their vocabulary level was investigated, as well as the relationship between VLS and metacognition.

The following research questions that were addressed in this study are:

1. What is the vocabulary level of new varsity learners?

2. What is the frequency of the vocabulary learning strategies used?

$3 . \quad$ What is the correlation between the respondents' vocabulary level and their perceived use of strategies in each of the four (4) ELVS parts/dimensions while they were at school and at the university.

4. What is the correlation between the respondents' overall English vocabulary learning strategy (EVLS) use while they were at school and their use similar strategies while they are at the university?

Is there a significant difference between the respondents' perceived use of English vocabulary learning strategies (EVLS) while they were at school and that while they were at university?

\section{METHODOLOGY}

244 first year students from seven (7) science and five (5) social sciences academic programmes at a local university participated in the study. Multi-stage cluster sampling was utilised in the selection process of the study. Fourty-nine of the participants were male and two hundred fourty-four participants were female.

The students were administered the Vocabulary Levels Test (VLT) to determine their vocabulary level. This test, designed by Nation [6], was used to assess the vocabulary levels of test takers. Respondents were tested at four levels (2000, 3000, 5000, 10,000 word levels) and each level contain 30 tested items. The respondents had to match the meaning of the tested words to the given choices.

After completing the VLT, respondents were asked to fill in the English Vocabulary Learning Strategies Questionnaire (EVLSQ) and the Metacognitive Awareness Inventory (MAI). The EVLSQ was used to gain insight to the strategies that the respondents utilised at school level and at the university. The ELVSQ was divided into two parts; Part 1 to obtain participants demographic and background information and Part 2, to obtain participants response on their English Vocabulary Learning Strategies. The Metacognitive Awareness Inventory [7] contains 52 items whereby the respondents had to respond whether the statements given were true or false in relation to their performance and planning strategies.

\section{RESULTS AND DISCUSSION}

The data was analysed using SPSS version 21. Descriptive statistics were utilised to obtain the information regarding students' vocabulary level as well as their usage of vocabulary learning strategies.

RQ1: What is the vocabulary level of new varsity learners?

Students' vocabulary levels are reported in Table 1 . Table 1 shows that only $22 \%$ of the sample achieved the 3000 and above vocabulary level. Almost half the sample did not achieve the 2000 word level. None of the respondents achieved the highest level tested that is the 10,000 vocabulary level.

Table 1 Vocabulary Levels

\begin{tabular}{lcccc}
\hline \hline Level & Frequency & Percent & $\begin{array}{c}\text { Valid } \\
\text { Percent }\end{array}$ & $\begin{array}{c}\text { Cumulative } \\
\text { Percent }\end{array}$ \\
\hline below level & 107 & 43.9 & 43.9 & 43.9 \\
2000 & 82 & 33.6 & 33.6 & 77.5 \\
Level 2000 & 49 & 20.1 & 20.1 & 97.5 \\
Level 3000 & 6 & 2.5 & 2.5 & 100.0 \\
Level 5000 & 244 & 100.0 & 100.0 & \\
Total &
\end{tabular}

Table 2 presents the reliability of the questionnaire used to measure students' use of Vocabulary Learning Strategies. The calculated reliability value was high at .963. This shows that the questionnaire used was highly reliable.

Table 2 : Reliability of ELVSQ

\begin{tabular}{cc}
\hline \hline Cronbach's Alpha & N of Items \\
\hline .963 & 35 \\
\end{tabular}

RQ2: What is the frequency of the vocabulary learning strategies used?

From the responses to the ELVSQ, it was noted the highest usage of the Vocabulary Learning Strategy almost $50 \%$ of the respondents said they tried to recall the meaning of a word when reading, nearly $40 \%$ often look up the meaning of words in the dictionary, $33 \%$ reported that they used bilingual dictionaries and $90 \%$ of the respondents said that they marked the words they wanted to focus on. On the other hand, most students reported that seldom planned their vocabulary learning, about $80 \%$ did not strategise by vocabulary learning by finding a mother-tongue equivalent and the same number of respondents also did not group words in order to learn them. 


\begin{tabular}{|c|c|c|c|c|}
\hline $\begin{array}{l}\text { Section } \\
\text { Reported } \\
\text { Usage }\end{array}$ & $\begin{array}{c}\text { Section A: General } \\
\text { Vocabulary Strategies }\end{array}$ & $\begin{array}{c}\text { Section B: Vocabulary } \\
\text { \& Reading }\end{array}$ & $\begin{array}{c}\text { Section C: Dictionary } \\
\text { Usage }\end{array}$ & $\begin{array}{l}\text { Section D: Learning } \\
\text { New Words }\end{array}$ \\
\hline Highest & $\begin{array}{c}45 \% \text { (Often) } \\
\text { A6 -Recall meaning of word }\end{array}$ & $\begin{array}{c}38.9 \%(\text { Often }) \\
\text { B16 - Look up dictionary }\end{array}$ & $\begin{array}{c}33.2 \% \text { (Often) } \\
\text { C20-Used bilingual } \\
\text { dictionary }\end{array}$ & $\begin{array}{c}90 \%(\text { Often }) \\
\text { D27-Mark the words } \\
\text { to learn }\end{array}$ \\
\hline Lowest & $\begin{array}{c}36 \%(\text { Seldom }) \\
\text { A3 - Plan their vocabulary } \\
\text { learning }\end{array}$ & $\begin{array}{c}41 \% \text { (Never) } \\
\text { B17-Did not do anything } \\
\text { about it }\end{array}$ & $\begin{array}{c}82 \% \text { (Seldom) } \\
\text { C21 - Find mother-tongue } \\
\text { equivalent }\end{array}$ & $\begin{array}{c}84 \% \text { (Seldom) } \\
\text { D28-Group words }\end{array}$ \\
\hline
\end{tabular}

Figure 1 Highest and Lowest reported used of Vocabulary Learning Strategy

RQ3: What is the correlation between the respondents' vocabulary level and their perceived use of strategies in each of the four (4) ELVS parts/dimensions while they were at school and at the university.

\begin{tabular}{|c|c|c|c|c|c|c|c|c|c|}
\hline Correlations & 1 & 2 & 3 & 4 & 5 & 6 & 7 & 8 & 9 \\
\hline VOCAB_LEVEL & 1 & & & & & & & & \\
\hline GENERAL_SECONDARY_MEAN & $.201^{* *}$ & 1 & & & & & & & \\
\hline VOCAB_READ_SECONDARY_MEAN & $.176^{* *}$ & $.400^{* * *}$ & 1 & & & & & & \\
\hline DICTIONARY_SECONDARY_MEAN & $.215^{* *}$ & $.512^{* * *}$ & $.613^{* *}$ & 1 & & & & & \\
\hline NEW_WORDS_SECONDARY_MEAN & .118 & $.510^{* *}$ & $.485^{* *}$ & $.673^{* *}$ & 1 & & & & \\
\hline GENERAL_UNIVERSITY_MEAN & .086 & $.464^{* *}$ & $.298^{* *}$ & $.393^{* *}$ & $.288^{* *}$ & 1 & & & \\
\hline VOCAB_READ_UNIVERSITY_MEAN & $.187^{* *}$ & $.246^{* * *}$ & $.717^{* *}$ & $.414^{* *}$ & $.313^{* *}$ & $.312^{* *}$ & 1 & & \\
\hline DICTIONARY_UNIVERSITY_MEAN & $.157^{*}$ & $.332^{* * *}$ & $.491^{* *}$ & $.757^{* *}$ & $.504^{* *}$ & $.407^{* *}$ & $.577^{* *}$ & 1 & \\
\hline NEW_WORDS_UNVERSITY_MEAN & .121 & $.281^{* *}$ & $.357^{* *}$ & $.504^{* *}$ & $.719^{* *}$ & $.439^{* *}$ & $.438^{* *}$ & $.611^{* *}$ & 1 \\
\hline
\end{tabular}

Results of the Pearson Product-Moment Correlation analysis shows that the respondents' vocabulary level positively and significantly correlated with perceived use of strategies in two parts of ELVS for both learning situations (i.e., at school \& at the university), however the strength of the correlations are wear $(\mathrm{r}$ $<.30)$.

a) Vocabulary \& Reading (at school, $r=.176^{* *}$, at university $\mathrm{r}=.187^{* * *}$ )

b) Dictionary Usage (at school, $r=.215^{* * *}$, at university $\mathrm{r}=.157^{*}$ )

Significant correlation was also found between the respondents' vocabulary level and perceived use of strategies in the General Vocabulary Learning Strategies part of the ELVS, but only for their responses regarding the use of such strategies while they were at school.

RQ4: What is the correlation between the respondents' overall English vocabulary learning strategy (EVLS) use while they were at school and their use similar strategies while they are at the university?

Table 3 shows the correlation between the respondents' perceived overall English vocabulary learning strategy use while they were at school and their perceived use of similar strategies while they are in university. The result of the Pearson Product-Moment Correlation analysis showed that the respondents' perceived overall use of EVL strategies while they were at school was significantly and positively correlated with their use of 
similar strategies while they were at the university. The calculated correlation value was high_( $r=.684)$ indicating a strong relationship between the two variables. The respondents' perceived high use of strategies while they were at school associated with their perceived high use of similar strategies at the university.

Table 3. Pearson Product-Moment Correlation Coefficient Between Perceived Overall Vocabulary Learning

Strategies use while the respondents were at school and the perceived strategy use while they were at the university

\begin{tabular}{llll} 
& & & \\
& & 1 & 2 \\
\hline $\begin{array}{l}\text { Overall Vocabulary } \\
\text { used at school }\end{array}$ & Strategies & 1 & \\
$\begin{array}{l}\text { Overall Vocabulary } \\
\text { used at university }\end{array}$ & Strategies &. \\
\hline
\end{tabular}

**Correlation is significant at 0.01 level (2-tailed)

* Correlation is significant at 0.05 level (2-tailed)

Note: $\mathrm{N}=244$
RQ5: Is there a significant difference between the respondents' perceived use of English vocabulary learning strategies (EVLS) while they were at school and that while they were at university?

There was also a difference between the respondents' perceived use of English vocabulary learning strategies (EVLS) while they were at school and that while they were at university. The results of the paired-samples t-test revealed a statistically significant difference between the respondents' response (score) on their perceived use of strategies while they were at their secondary school and their response on the perceived use of the same strategies while they are at the university $(\mathrm{t}(243)=5.283, \mathrm{p}<.01)$. The calculated mean (M) for the response score while the respondents are at the university is higher $(\mathrm{M}=110.93)$ than the one obtained while they were at school $(\mathrm{M}=105.34)$. This indicates that there was a significant increase in the respondents' use of strategies when they entered the university.

Table 4 Correlation between vocabulary strategies and general meta cognitive awareness

\begin{tabular}{|c|c|c|c|c|c|c|}
\hline Correlations & $\begin{array}{l}\text { MUET } \\
\text { D } \\
\end{array}$ & SPM & At school & At University & Vocab_Level & Metacognition \\
\hline MUET_BAND & 1 & & & & & \\
\hline SPM & $.438^{* *}$ & 1 & & & & \\
\hline At School & .088 & $.235^{* *}$ & 1 & & & \\
\hline At University & -.029 & .067 & $.684^{* *}$ & 1 & & \\
\hline Vocab_Level & $.369^{* *}$ & $.276^{* *}$ & $.214^{* *}$ & $.163^{*}$ & 1 & \\
\hline Metacognition & .011 & .106 & $.316^{* *}$ & $.335^{* *}$ & .036 & 1 \\
\hline
\end{tabular}

\section{CONCLUSION}

From the results obtained which concurs with local studies carried out previously that indicate that Malaysian tertiary learners do not have English language vocabulary. This is also similar to findings on vocabulary knowledge among undergraduates in Asia [8]. Although the respondents reported that they used some vocabulary learning strategies, they were not often utilised. Furthermore, using these strategies was incidental and not planned. Almost all the respondents did not plan their vocabulary learning.
Among the vocabulary learning strategy commonly used is the utilisation of bilingual dictionary. This low-level strategy is linked with students with lower level of language proficiency [9]. The finding of this research is similar with Gu and Johnson (1996) [10], and Komol and Sripetpun (2014) [11] who indicated students with low frequency usage of vocabulary learning strategies have lesser vocabulary knowledge and vice versa.

Graham and Macaro (2008) [12] have said that lower level learners would gain from strategy instruction although there has been some research [13]-[14] that indicates lower 
level learners seldom utilise metacognitive strategies because they spend most of their time understanding the stimuli/input itself.

From the results of this study, metacognition is found to be positively correlated to Vocabulary learning strategies. Although the correlation may be small/slight. Studies on the direct teaching or intervention of vocabulary learning strategies will help establish which strategies the participants will be more willing to utilise. These will help the language instruction process especially in create a vocabulary learning awareness as well as to inculcate employment of metacognitive strategies in increasing English vocabulary.

\section{REFERENCES}

[1] H. Aziz, Malaysia drops 9 spots in English proficiency ranking for non-native speakers. News Straits Times. 2018. https://www.nst.com.my/education/2018/10/426949/ma laysia-drops-9-spots-english-proficiency-ranking-nonnative-speakers

[2] B. Laufer, How much lexis is necessary for reading comprehension? In P. J. L. Arnaud, \& H. Bejoing (Eds.), Vocabulary and Applied Linguistics (pp. 129132). London: Macmillan.

[3] S. Hazenberg and J. H. Hulstijn, Defining a minimal receptive second-language vocabulary for non-native university students: An empirical investigation. Applied linguistics, 17(2) (1996) 145-163.

[4] S. Adolphs, and N. Schmitt, Lexical coverage of spoken discourse. Applied linguistics 24(4) (2003) 425438 .

[5] H. van Zeeland and N. Schmitt, N. (2013). Incidental vocabulary acquisition through L2 listening: A dimensions approach. System, 41 (2013) 609-624.

[6] I. S. P. Nation, Teaching and Learning Vocabulary. Boston, Massachusetts. Heinle \& Heinle Publishers. 1990.

[7] G. Schraw and R. S. Dennison, Assessing metacognitive awareness. Contemporary educational psychology, 19(4) (1994) 460-475.

[8] A. Nurweni, and J. Read, The English vocabulary knowledge of Indonesian university students. English for Specific Purposes, 18(2), (1999) 161-175

[9] M. Ahmed, Vocabulary learning strategies. In P. Meara (ed). Beyond Words. London: CILT.1989.

[10] Y. Gu and R. K. Johnson, Vocabulary learning strategies and language learning outcomes. Language learning, 46(4) (1996) 643-679.
[11] T. Komol and W. Sripetpun, Vocabulary learning strategies employed by undergraduate students and its relationship to their vocabulary knowledge. 2014. DOI: http://tar.thailis.or.th/handle/123456789/667

[12] S. Graham and E. Macaro, Strategy instruction in listening for lower-intermediate learners of French. Language learning, 58(4) (2008) 747-783. DOI: $10.1111 / \mathrm{j} .1467-9922.2008 .00478 . x$

[13] J. Rubin, A review of second language listening comprehension research. The modern language journal, 78(2) (1994) 199-221. http://dx.doi.org/10.2307/329010

[14] L. Vandergrift and S. Baker, Learner variables in second language listening comprehension: an exploratory path analysis. Language learning, 65(2) (2015) 390-416. https://doi.org/10.1111/lang.12105 